J.P.M. Bonenkamp, J.P.A.M. Jacobs en J.P. Smits

\title{
DETERMINANTEN VAN DE CONSUMPTIEVE VRAAG IN NEDERLAND, 1815-1913
}

\begin{abstract}
Determinants of consumption demand in the Netherlands I8I5-I9I3
This article investigates consumption demand in the Netherlands in the nineteenth century. First it is formally established whether sub periods can be discerned in the development of consumption. Then dynamic consumption models are estimated that distinguish both long-term and short-run behaviour. The article concludes that the derived classification of sub periods in consumption is more or less in line with existing views. However, the relation between consumption and its determinants, real wage, excises, unemployment and the real interest rate, changes over the sample. Real wages and excises play a role throughout the nineteenth century, whereas the impact of the real interest rate and unemployment is confined to the beginning of the period of modern economic growth.
\end{abstract}

\section{$1 \quad$ Inleiding}

Generaties economisch-historici hebben zich al over de vraag gebogen op welke wijze het groeiproces van de Nederlandse economie in de negentiende eeuw het beste kan worden gekarakteriseerd. Het staat buiten kijf dat de economische groei in dit tijdvak minder indrukwekkend was dan tijdens de Gouden Eeuw of gedurende de 'lange industrialisatiegolf' in de periode I920I960. Tot voor kort ontbrak het evenwel aan goed cijfermateriaal om de ontwikkeling van de Nederlandse volkshuishouding op een goede manier in kaart te brengen.

Door de verwezenlijking van het project 'Reconstructie Nationale Rekeningen van Nederland' is de economische ontwikkeling van de negentiende eeuw in een ander licht komen te staan. Op basis van deze nieuwe dataset omtrent de sociaal-economische ontwikkeling van de negentiende eeuw, blijkt dat het groeiproces in die eeuw vrij evenwichtig was. ${ }^{\mathrm{I}}$ Al vanaf I820 is er sprake van eco-

1. J.P. Smits, E. Horlings en J.L. van Zanden, Dutch GNP and its components, 1800-1913 (Groningen 2000) en H.H. van Ark, H.J. de Jong en J.P. Smits, 'Three phases of Dutch economic growth and technological change, I8I5-I997', in: Research Memorandum GD 42 (Groningen Growth and Development Centre, Groningen I999). 
nomische groei, niet gedreven door de industriële sector maar door de agrarische sector en de dienstensector. Een van de meest intrigerende uitkomsten van het nationale rekeningenproject is dat het groeipatroon van het bruto binnenlands product stabiel is, terwijl onderliggende reeksen met betrekking tot de inkomensverdeling en de bestedingenstructuur scherpe breuken te zien geven.

In dit artikel wordt de ontwikkeling van de consumptieve vraag in de negentiende eeuw onder de loep genomen. Op regionaal en lokaal niveau is al veel werk op dit gebied gedaan. Met name het baanbrekende werk van A. Knotter en H. Muskee naar Amsterdam dient in dit kader te worden genoemd. ${ }^{2}$ Ook het werk van J. de Meere naar de ontwikkeling van de levensstandaard in de ruimste zin van het woord is richtinggevend geweest in het historiografisch debat. ${ }^{3}$ Echter voor al deze studies geldt dat de consumptiecijfers niet op nationaal niveau beschikbaar zijn. Daarnaast beperken de cijfers zich veelal tot het consumptiepatroon van de arbeidende klasse. Vanuit sociaal-historisch oogpunt zijn deze cijfers uiteraard interessant, vanuit een economisch-historische optiek dient echter ook de consumptie van boeren en hogere inkomensgroepen in de analyse te worden betrokken.

Wij onderwerpen in het bijzonder de relatie tussen consumptie en economische groei aan een gedetailleerde analyse. Eerder onderzoek heeft aangetoond dat deze relatie in de loop van de negentiende eeuw alles behalve constant en eenduidig is. ${ }^{4}$ In dat verband is met name gewezen op het instabiele verloop van de voedselprijzen, de reële lonen en de indirecte belastingen op consumptiegoederen. Tot dusver is nog niet in kaart gebracht wat de relatieve bijdragen zijn geweest van de determinanten van de consumptieve vraag in de negentiende eeuw. Daarom wordt in dit artikel met behulp van een formele, econometrische analyse gekeken welke factoren de consumptieve bestedingen hebben aangestuurd over de gehele periode en over deelperioden. Onze analyse levert een aantal interessante gezichtspunten op die een bijdrage kunnen leveren voor een dieper inzicht in het proces van moderne economische groei in Nederland. Zo blijkt er in de eerste helft van de negentiende eeuw geen sprake te zijn geweest van een langetermijn evenwichtsrelatie voor consumptie. In de tweede helft van de eeuw is dat wel het geval geweest. Daarnaast zijn de tijdreekseigenschappen in de eerste en de tweede helft van de eeuw verschillend.

2. A. Knotter en H. Muskee, 'Conjunctuur en levensstandaard in Amsterdam I8I5-I855: een onderzoek op basis van plaatselijke accijnzen', in: Tijdschrift voor Sociale Geschiedenis I2 (I986) I53-I8I.

3. J.M.M. de Meere, Economische ontwikkeling en levensstandaard in Nederland gedurende de eerste helft van de negentiende eeuw; aspecten en trends (Den Haag I982).

4. E. Horlings en J.P. Smits, 'Private consumer expenditure in the Netherlands', in: Economic and social history in the Netherlands 7 (I996) I5-40. 
Het artikel is als volgt opgebouwd. In paragraaf twee wordt kort nagegaan tot welke inzichten economisch-historici tot dusverre zijn gekomen op dit terrein. Vervolgens wordt in paragraaf drie de econometrische methode beschreven; in paragraaf vier worden de gebruikte cijferreeksen geïntroduceerd. Daarna wordt in paragraaf vijf gekeken welk licht deze econometrische benadering werpt op de ontwikkeling van de consumptie in de negentiende eeuw. Paragraaf zes geeft een samenvatting van onze bevindingen.

\section{Consumptie in de negentiende eeuw: huidige inzichten}

De meeste studies die betrekking hebben op de sociaal-economische geschiedenis van Nederland in de negentiende eeuw zijn gericht op het beschrijven en analyseren van de economische ontwikkeling, zowel in ruime zin als vanuit een sectorale invalshoek. ${ }^{5}$ Het accent in deze studies ligt in veel gevallen op de opkomst en timing van de industrialisatie. ${ }^{6}$ Tot voor kort ontbraken voldoende betrouwbare gegevens die een analyse van aspecten van economische ontwikkeling (zoals de consumptieve ontwikkeling) mogelijk maakten.

De totstandkoming en afronding van het nationale rekeningenproject heeft in dit opzicht vele ingangen geopend voor een meer specifieke kijk op de economische ontwikkeling. De empirische analyse van de consumptieve bestedingen in de negentiende eeuw op nationaal niveau begint bij E. Horlings en J.P. Smits. ${ }^{7}$ De informatie voor deze paragraaf is in hoge mate ontleend aan hun artikel.

Wat betreft de eerste helft van de negentiende eeuw brengen Smits en Horlings de ontwikkeling van de consumptieve bestedingen in nauw verband met het verloop van de (primaire) voedselprijzen. De ontwikkeling van de koopkracht, doorgaans de belangrijkste determinant van de consumptieve groei, werd in hun ogen voornamelijk bepaald door de fluctuaties van de landbouwprijzen. ${ }^{8}$ Dit heeft alles te maken met het feit dat in de eerste helft van de

5. I.J. Brugmans, Paardenkracht en mensenmacht. Sociaal-economische geschiedenis van Nederland 1795-1940 (Den Haag I96I) is een voorbeeld van de eerste categorie, J.L. van Zanden en A. van Riel, Nederland 1780-1914. Staat, instituties en economische ontwikkeling (Meppel 2000) van de tweede categorie.

6. Brugmans, Paardenkracht; J.A. de Jonge, De industrialisatie in Nederland tussen 1850 en 1914 (Amsterdam I968); R.T. Griffiths, Industrial retardation in the Netherlands 1830-1850 (Den Haag I979) en Van Ark e.a., 'Three phases of Dutch economic growth'.

7. E. Horlings en J.P. Smits, 'Private consumer expenditure'. Voor de ontwikkeling van facetten van economische ontwikkeling in de negentiende eeuw als lonen, nationaal vermogen en investeringen in het spoorwegennet wordt verwezen naar andere artikelen uit de N EHA-publicatie Economic and social history in the Netherland 7 (Amsterdam I996).

8. Horlings en Smits, 'Private consumer expenditure', 29-30. 
negentiende eeuw voedingsmiddelen in het totale consumptiepakket het grootste aandeel hadden.

In de eerste helft van de negentiende eeuw, of om precies te zijn tot halverwege de jaren veertig, namen de voedingsmiddelen gemiddeld zo'n 60 procent in van de totale consumptie. ${ }^{9}$ De gestage toename van de consumptie in die periode (gemiddeld met zo'n I,7 procent) vindt grotendeels een verklaring in de stijgende reële lonen na I8I7 onder invloed van de dalende voedselprijzen. ${ }^{\text {Io }}$ De groei van de productie in de jaren twintig werd hoofdzakelijk gedragen door een stijging van de binnenlandse vraag, waar de consumptie met een groei van I,7 procent per jaar een belangrijke bijdrage aan leverde. ${ }^{\text {II }}$

De liberalisatie van de handel in de jaren veertig leidde tot een forse toename in de export van agrarische producten. Het gevolg hiervan was dat de binnenlandse landbouwprijzen gingen stijgen waardoor de koopkracht van de bevolking onder druk kwam te staan. Niet langer was de binnenlandse vraag, maar de handel met het buitenland (met name met Java) de drijvende kracht achter de economische groei. ${ }^{\text {I2 }}$ De stijging van de landbouwprijzen werd nog versterkt door misoogsten in de jaren I847 en I854. Het is derhalve niet verwonderlijk dat de groei van de totale consumptie in de periode I845-I865 gemiddeld met o,8 procent per jaar is afgenomen.

De private consumptieve bestedingen volgden in de tweede helft van de negentiende eeuw een volstrekt ander groeipad. Vanaf I865 was er sprake van een enorme toename van de consumptieve bestedingen. In de periode I865-I880 stegen de reële consumptieve uitgaven met gemiddeld 3, I procent per jaar, terwijl de voorgaande twee decennia een groei lieten zien van slechts o,9 procent. Wat betreft de oorsprong van deze enorme stijging in de consumptie wijzen Horlings en Smits op de herziening van het belastingstelsel op grond waarvan de prijzen van (primaire) voedingsmiddelen relatief sterk daalden. Hierdoor konden gezinnen een groter deel van hun budget besteden aan luxe voedings- en genotmiddelen, kleding en andere industriële producten. ${ }^{\mathrm{I} 3}$ Deze tendens werd versterkt toen de nominale lonen, als gevolg van een toenemende krapte op delen van de arbeidsmarkt, fors begonnen te stijgen. ${ }^{\text {I4 }}$ De stijging van de consumptieve bestedingen ging dus gepaard met aanzienlijke veranderingen in het bestedingspatroon. ${ }^{\text {I5 }}$

9. Tenzij anders vermeld, zijn de vermelde percentages in dit artikel berekend op basis van de gegevens uit Smits e.a., Dutch GNP.

10. Van Zanden en Van Riel, Nederland 1780-1914, I52 en Horlings en Smits, 'Private consumer expenditure', 22.

11. Van Zanden en Van Riel, Nederland 1780-1914, I68.

12. Horlings en Smits, 'Private consumer expenditure', 22.

13. Horlings en Smits, 'Private consumer expenditure', 27.

14. A. Vermaas en A. Burger, 'Dutch industrial wage development in an international perspective, I850-I9I3', in: Economic and social history in the Netherlands 7 (I996) I09-I33.

15. Van Zanden en Van Riel, Nederland 1780-1914, 355. 
De forse stijging van de binnenlandse vraag maakte het voor bedrijven (eindelijk) mogelijk om op grote schaal te produceren. Het verdwijnen van schaalrestricties, overigens versterkt door de afname van de internationale protectie, maakten investeringen in 'nieuwe' (stoom)technologieën rendabel. Tussen I850 en I890 nam het aandeel van de stoommachine in de totale machinerie toe van 5 procent tot ruim 60 procent. ${ }^{16}$ De eerste fase van moderne economische groei, de opkomst van de industrialisatie in Nederland in de jaren zestig en zeventig, hing dus nauw samen met de stijging van de binnenlandse consumptie in die periode.

De tweede fase van moderne economische groei, van I880-I9I3, gaf een ander beeld te zien. Na i88o vlakte de hoge groei van de consumptie af en werden de investeringen geleidelijk de drijvende kracht achter de economische groei. Hoewel een jaarlijkse stijging van 2,6 procent nog altijd heel behoorlijk is, nam de groei van de consumptie met 0,5 procentpunt af ten opzichte van de voorgaande twee decennia. In de literatuur wordt geen directe verklaring gegeven voor de afname in de consumptiegroei. Een mogelijke verklaring kan gevonden worden in het feit dat in de periode I894-I9I3 veel investeringen gericht waren op de substitutie van arbeid voor kapitaalgoederen. ${ }^{17}$ Dit substitutieproces leidt tot een verandering in de schaarsteverhoudingen hetgeen zijn invloed zal hebben op de beloning voor de productiefactoren. Als kapitaal schaarser wordt zal de beloning ervan ten opzichte van die van arbeid stijgen. Veronderstellende dat het arbeidsloon voornamelijk besteed wordt aan consumptiegoederen en kapitaalinkomen gespaard wordt, kan een (relatieve) toename van het kapitaalinkomen een verklaring bieden voor de afname in de consumptiegroei. Smits laat inderdaad zien dat de verhouding tussen het arbeidsloon en kapitaalloon in de periode I895-I9I3 afneemt. ${ }^{\text {I8 }}$

De sterke toename in de investeringen werd grotendeels bepaald door de enorme toename van de wereldhandel. Tot ongeveer I89o waren de investeringen voornamelijk gericht op de implementatie van de technieken van de Britse eerste industriële revolutie, de revolutie van staal, steenkool en stoomenergie. Vanaf I89o dienden zich andere krachten aan. De ontwikkeling van de Nederlandse industrie werd in toenemende mate gekenmerkt door de tweede industriële revolutie, gebaseerd op macro-innovaties rond het gebruik van elektriciteit. De productiecapaciteit nam zodoende fors toe, waardoor de Nederlandse bedrijven voortaan ook in de exportvraag konden voorzien. In de periode I890-I9I3 namen de investeringen gemiddeld met liefst 3,3 procent per jaar toe, de consumptie steeg in deze periode met 2,4 procent.

16. Van Ark e.a., 'Three phases of Dutch economic growth', II.

17. Van Zanden en Van Riel (2000), Nederland 1780-1914, 350-351.

18. J.P. Smits, 'The determinants of productivity growth in Dutch manufacturing, I8I5I9I3, in: European Review of Economic History 4 (2000) 246. 
Een belangrijke conclusie die uit deze paragraaf naar voren komt, is het bestaan van deelperioden in de ontwikkeling van de consumptieve vraag in Nederland in de negentiende eeuw. In ons empirisch onderzoek in het vervolg van dit artikel kijken we daarom zowel naar de gehele periode als naar deelperioden.

\section{Methode}

\section{Periodisering}

In dit artikel gebruiken we de volgende statistische procedure om deelperioden te onderscheiden. ${ }^{\text {I9 }}$ Gegeven een modelspecificatie wordt de schattingsperiode in tweeën gesplitst op (successievelijk) elk mogelijk jaar. Voor beide deelperioden worden met behulp van de kleinste kwadraten methode de parameters van het model geschat en de som van de gekwadrateerde residuen berekend. Het jaar waarin de som van de gekwadrateerde residuen van beide deelperioden tezamen zijn globale minimum bereikt, is een breukjaar. Als de som van de gekwadrateerde residuen (als functie van het breukjaar) naast een globaal minimum ook lokale minima bevat, zal een nadere uitsplitsing van de steekproef moeten uitwijzen of die jaren ook voor (geschatte) breukjaren in aanmerking komen. ${ }^{20}$

Een belangrijk element is de keuze van het model waarmee de reeksbreuken worden opgespoord. Omdat onze interesse uitgaat uit naar deelperioden in consumptie, hanteren wij een univariaat model, dit is een model met slechts één variabele, om precies te zijn de vergelijking die wordt gebruikt voor het toetsen van tijdreekseigenschappen. Deze zogenoemde Augmented Dickey Fuller (ADF) vergelijking heeft voor een tijdreeks $y_{t}$ de volgende vorm:

$$
\Delta \gamma_{t}=\alpha_{1}+\alpha_{2} t+\alpha_{3} \gamma_{t-1}+\alpha_{4} \Delta \gamma_{t-1}+\varepsilon_{t}
$$

Het deltateken (' $\Delta$ ') impliceert dat van een variabele het eerste verschil (dit komt ongeveer overeen met de groei op jaarbasis) wordt genomen, dat wil zeggen, $\Delta \gamma_{t}=\left(\gamma_{t}-\gamma_{t-1}\right)$. In vergelijking (I) wordt dat eerste verschil $\left(\Delta \gamma_{t}\right)$ verklaard door een constante $\left(\alpha_{1}\right)$, een deterministische trend $\left(\alpha_{2} t\right)$ en één vertraagde endogene variabele $\left(\alpha_{4} \Delta \gamma_{t-1}\right)$. Een storingsterm $\left(\varepsilon_{t}\right)$ complementeert de vergelij-

\footnotetext{
19. Voor een uitgebreidere beschrijving zie B.E. Hansen, 'The new econometrics of structural change: dating changes in U.s. labor productivity', in: Journal of Economic Perspectives I5 (200I) II7-I28.

20. Bovenstaande methode levert alleen een indicatie op dat er een breukjaar is. Een meer rigoureuze aanpak vereist nog een formele toetsing van de structuurbreuk, in het bijzonder of de modelspecificatie voor en na de breuk van elkaar verschilt. Deze stap, waarin nietstandaard statistische theorie wordt gebruikt, laten we in dit artikel achterwege.
} 
king. De parameter $\alpha_{3}$ speelt een belangrijke rol bij het toetsen van tijdreekseigenschappen. Als $\alpha_{3}$ niet significant afwijkt van nul, kan de nulhypothese dat de reeks een eenheidswortel heeft en daarmee niet-stationair is, niet worden verworpen. In dit geval is het eerste verschil van de reeks, $\Delta \gamma_{t}$, stationair. ${ }^{2 \mathrm{I}}$ Dit wordt aangegeven met $\gamma_{t} \sim \mathrm{I}(\mathrm{I})$. Als $\alpha_{3}$ significant negatief is, kan worden aangenomen dat $\gamma_{t}$ stationair is, en schrijven we $\gamma_{t} \sim \mathrm{I}(\mathrm{o})$. Als toetsgrootheid voor parameter $\alpha_{3}$ kan de gewone $t$-statistiek worden gebruikt. Echter, deze statistiek volgt niet de standaard $t$-verdeling onder de nulhypothese.

Het opsporen van reeksbreuken met de som van de gekwadrateerde residuen is niet noodzakelijkerwijs gebonden aan een univariate modelspecificatie. Het kan ook met een multivariaat model, in ons geval een model waarin consumptie afhankelijk wordt gesteld van een aantal determinanten. Hier kleeft echter een nadeel aan dat samenhangt met het feit dat een multivariaat model niet beschrijvend is maar verklarend. Als de consumptie en (één van) de determinanten namelijk in hetzelfde jaar een reeksbreuk hebben, zal het multivariate model geen reeksbreuken oppikken. Om die reden prefereren wij een univariaat model voor de periodisering.

\section{Consumptievergelijking}

Als uitgangspunt voor het schatten van de consumptievergelijking nemen we de dynamische specificatie van Davidson e.a., het zogenoemde error correctie model (ECM). ${ }^{22}$ In een ECM spelen afwijkingen van het langetermijn evenwicht een rol bij de kortetermijn aanpassingen. ${ }^{23}$ De algemene gedaante van een ECM is volgt:

$$
\Delta c_{t}=\alpha^{\prime} \Delta X_{t}-\gamma\left(c_{t-1}-\beta^{\prime} X_{t-1}\right)+\varepsilon_{t}
$$

De symbolen in vergelijking (2) hebben de volgende betekenis: $c_{t}$ staat voor de private consumptie in jaar $t, X$ is een vector van determinanten van de consumptieve bestedingen, zowel $\alpha$ als $\beta$ zijn kolomvectoren die de korte- respectievelijk langetermijn elasticiteiten bevatten, $\gamma$ is een aanpassingsparameter

21. Een praktische definitie van stationariteit is de volgende: een tijdreeks is stationair wanneer een schok direct is uitgewerkt en daarmee de reeks terugkeert naar zijn 'oorspronkelijke' pad.

22. J. Davidson e.a., 'Econometric modelling of the aggregate time-series relationship between consumers'expenditures and income in the U.K.', in: Economic Journal 88 (I978) 66I-692.

23. Er bestaat een één-op-één relatie tussen een ЕСм en co-integratie. We spreken van co-integratie als tussen twee of meerdere I(I)-reeksen een stabiel verband bestaat. Om een ECM empirisch invulling te geven, zouden we eerst voor de betreffende variabelen moeten toetsen of er lange-termijnverbanden tussen de variabelen bestaan en of aan de exogeniteitscondities is voldaan. 
die nog nadere toelichting behoeft en, tenslotte, $\varepsilon_{t}$ is een storingsterm. De constante is opgenomen in de lange termijn. Analoog aan vergelijking (I) geeft het deltateken (' $\Delta$ ') aan dat van een variabele het eerste verschil wordt genomen. In dit geval geldt dus: $\Delta c_{t}=c_{t}-c_{t-1}$.

In vergelijking (2) is de verandering in de consumptie $\left(\Delta c_{t}\right)$ de som van twee factoren. De eerste factor is de verandering in de determinanten van de consumptie $\left(\alpha^{\prime} \Delta X_{t}\right)$. De tweede factor is een aanpassing voor de mate waarin de consumptie afwijkt van het langetermijn evenwicht $\left(c_{t-1}-\beta^{\prime} X_{t-1}\right)$. Als de consumptie in het voorafgaande jaar ( $t-1)$ groter is dan zijn langetermijn evenwichtswaarde $\left(c_{t-1}-\beta^{\prime} X_{t-1}>0\right)$, vindt er in jaar $t$ een negatieve aanpassing plaats. Is de consumptie in het voorafgaande jaar lager dan het langetermijn evenwicht $\left(c_{t-1}-\beta^{\prime} X_{t-1}<0\right)$, dan is die aanpassing in $t$ positief. De coëfficiënt $\gamma$ geeft de aanpassingssnelheid weer, dat wil zeggen, in welke mate keert de consumptie terug naar het langetermijn evenwicht ingeval de consumptie op korte termijn daarvan afwijkt. Hoe hoger de $\gamma$, hoe sneller consumptie zich aanpast.

Onze invulling van de vector van consumptiedeterminanten $X$ sluit aan bij de standaard (Keynesiaanse) consumptietheorie van de twintigste eeuw als ook bij de economisch-historische context van de negentiende eeuw in Nederland. Dat betekent dat in ieder geval het reële loon en de interestvoet worden meegenomen, om recht te doen aan het transactiemotief en het voorzorgs-, speculatie- en risicoafkeermotief.

Directe belastingen in de negentiende eeuw waren klein qua omvang, in tegenstelling tot indirecte belastingen. Van de indirecte belastingen hebben met name de accijnzen in hoge mate invloed gehad op het consumptiepatroon in Nederland in de negentiende eeuw. ${ }^{24}$ Om die reden worden de accijnzen als percentage van de totale consumptie in de analyse betrokken. Het opleggen van accijnzen leidt rechtstreeks tot hogere prijzen voor consumenten, hetgeen van invloed zal zijn op hun consumptiebeslissingen.

De vector van consumptiedeterminanten wordt gecomplementeerd met werkloosheid en primaire voedselprijzen. Zoals beschreven in paragraaf twee spelen de primaire voedselprijzen vooral een rol in de eerste helft van de negentiende eeuw. In die periode, waarin verreweg het grootste deel van de consumptie bestond uit voedingsmiddelen, werd de koopkracht vrijwel volledig bepaald door de fluctuaties in de voedselprijzen.

\section{Data}

De tijdreeksen die in dit artikel zijn gebruikt voor het analyseren van de consumptieve bestedingen in de negentiende eeuw zijn op de interestvoet na ont-

24. Horlings en Smits, 'Private consumer expenditure', 26-32. 
leend aan Smits e.a. ${ }^{25}$ Deze dataset bevat de nationale rekeningen voor de gehele negentiende eeuw. De interestvoet is afkomstig van De Nederlandsche Bank. ${ }^{26}$ De reeksen zijn afgebeeld in Figuur I.

De eerste grafiek in Figuur I, linksboven, laat de private reële consumptie zien. De private consumptie is samengesteld uit de volgende goederen en diensten:

Consumptie

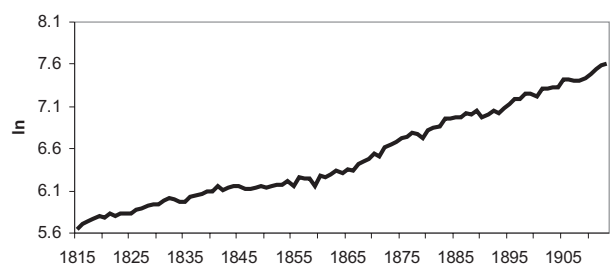

Accijnzen

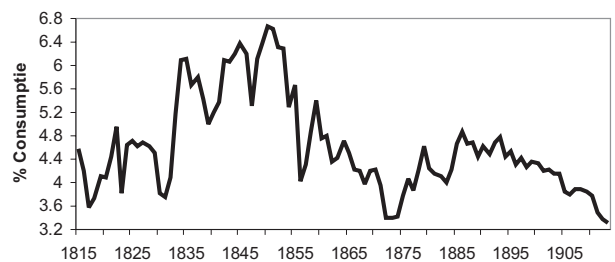

Werkloosheid

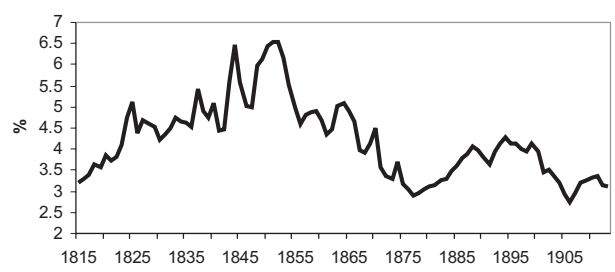

Reëel loon

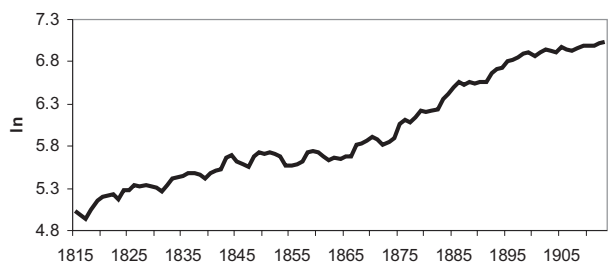

Rente

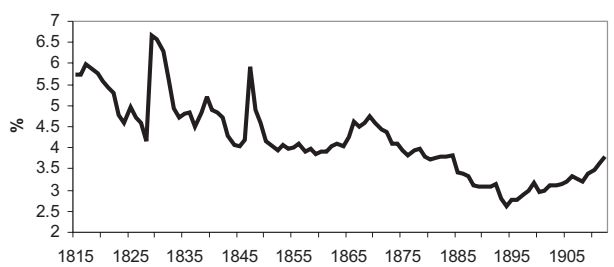

Voedselprijzen

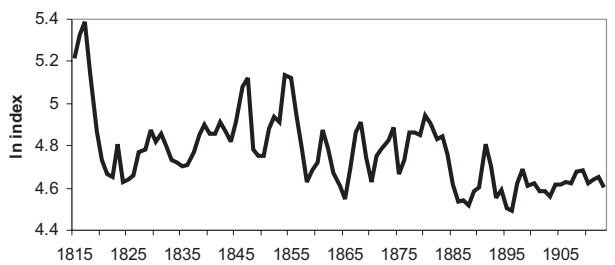

Fıgú 1 . Tijdreeksen consumptie en determinanten

25. Smits e.a.,Dutch GNP, II8-I20, I60-I62, I72-I74 en I76-I78.

26. W.F.-J. van de Poll, 'Bronbeschrijving gegevens voor onderzoek risicopremie Nederlandse aandelen', Onderzoeksmemorandum WOQE 465 (De Nederlandsche Bank, Amsterdam i996). 
1. Voedingsstoffen: aardappelen, bier, boter, brood, gedestilleerd water, kaas, koffie, melk, rijst, suiker, tabak, thee, tuinbouwproducten, vlees, wijn, zout en andere voedingsstoffen.

2. Industriële goederen: brandstof, kleding en overige industriële goederen.

3. Diensten: huur, huiselijke diensten, onderwijs, communicatie, transport en overige diensten.

De consumptie ontwikkelde zich in de negentiende eeuw vrij stabiel, hoewel er in de tweede helft duidelijk sprake is van een versnelling in het groeipatroon. De consumptie nam in de eerste helft met gemiddeld I,4 procent per jaar toe, terwijl de tweede helft gemiddeld genomen een groei laat zien van 2,6 procent.

Voor de reële lonen geldt in wezen hetzelfde. Rechtsboven in Figuur I staat de grafiek van de reële lonen. In de eerste helft van de negentiende eeuw stegen de lonen met gemiddeld I,3 procent per jaar, voor de tweede helft ligt dat percentage op 2,8 procent. In vergelijking tot de consumptie, verliep de ontwikkeling van de reële lonen beduidend minder stabiel, met name voor de eerste helft van de eeuw. De ontwikkeling van de reële lonen werd in de eerste helft van de negentiende eeuw vrijwel geheel bepaald door de fluctuaties in de voedselprijzen. Onder invloed van onder meer misoogsten schommelden de voedselprijzen in deze periode buitengewoon sterk.

In Figuur I, midden links, staat het verloop van de accijnzen weergegeven als percentage van de totale private consumptie. Deze ratio geeft in feite de belastingdruk weer op consumptiegoederen. Bij het bestuderen van deze grafiek valt in de eerste plaats de toename van de ratio in de periode I830-I850 op. Deze stijging houdt verband met de herziening van de belastingwet in het jaar I83I als gevolg waarvan de belastingdruk op (met name) primaire voedingsmiddelen verdubbelde. $\mathrm{Na}$ de Afscheiding van de Zuidelijke Nederlanden in I830, had de overheid dringende behoefte aan inkomsten. Ondanks het lagere welvaartsniveau in die regio, was de belastingdruk in het Zuiden hoger. Die inkomsten vielen na de Afscheiding weg. Met de accijnsverhogingen van I83I moest de consument hier letterlijk de tol voor betalen. In de periode I850I870 nam de belastingdruk sterk af. Waar de accijnzen in I850 nog ruim zes procent innamen van de totale consumptieve bestedingen, was dat percentage in 1872 gedaald tot een minimum van drie procent. In de loop van de jaren veertig werd - na de invoering van het Cultuurstelsel op Java - de inkomstenstroom vanuit Nederlandsch-Indië dermate groot, dat uit die gelden zowel belastingverlagingen als spoorwegen konden worden gefinancierd. De stijging van de belastingdruk in de periode I870-I885 hing samen met een terugval in de economische groei onder invloed van de Agrarische Depressie.

Midden rechts in Figuur I staat de grafiek van de interestvoet. In de eerste helft van de eeuw kende de interestvoet een aantal grote uitschieters; een kenmerk dat past bij een premodern economisch systeem dat nog altijd in hoge 
mate vatbaar is voor exogene schokken. Tot en met ongeveer I900 is de interestvoet, afgezien van de jaren zestig, licht gedaald. Deze lange trendmatige daling van de interestvoet hing waarschijnlijk samen met de grote kapitaalovervloed in die periode. Na I900 nam de interestvoet onder druk van de toenemende investeringslust toe.

De werkloosheid, in Figuur I linksonder, nam in de eerste helft van de eeuw fors toe, tot ongeveer I855; daarna zette een daling in die duurde tot en met I880. In de jaren tachtig nam de werkloosheid weer toe, zonder nochtans het hoge niveau van I855 te bereiken. Eind jaren tachtig daalde de werkloosheid weer onder invloed van de aantrekkende internationale conjunctuur.

Rechtsonder in Figuur I is de grafiek van de voedselprijzen weergegeven. Deze reeks is een gewogen gemiddelde van de prijsindex van aardappelen en brood. Hoewel het beeld enigszins wordt vertroebeld door de sterke fluctuaties, stegen de primaire voedselprijzen gemiddeld genomen tot ongeveer I850. Na de Krimoorlog (I853-I855) zette een scherpe daling in tot ongeveer I865. In de twee decennia die volgden steeg de gewogen index weer licht. Vanaf i88o nam de index wederom sterk af.

\section{Resultaten}

\section{Periodisering}

Visuele inspectie van de tijdreeks van consumptie in het paneel linksboven van Figuur I suggereert al het bestaan van deelperioden. Onze statistische methode levert een nadere onderbouwing. Figuur 2 laat de totale som van de gekwadrateerde residuen zien, weergegeven als functie van het breukjaar en voor het model van vergelijking (I). De som van de gekwadrateerde residuen heeft een globaal minimum in 1866 . De procedure is vervolgens herhaald voor de deelperioden I8I5-I865 en voor I866-I9I3. Op basis hiervan kwamen I845 en I889, de lokale minima in Figuur 2, ook als breukjaren in de consumptie naar voren. Kortom, in onze schattingen beneden onderscheiden we de volgende vier deelperioden: I. I8I5-I844, 2. I845-I865, 3. I866-I888 en 4. I889-I9I3.

De statistische econometrische methode die in dit artikel is gebruikt om reeksbreuken in de consumptie op te sporen sluit goed aan bij de meer inductieve, empirische aanpak die Horlings en Smits hanteren. Hun periodisering stemt grotendeels overeen met de bovenstaande indeling. Het enige verschil spitst zich toe op het einde van de eeuw. Op basis van onze methode komt I889 er als breukjaar uit; Horlings en Smits leggen deze breuk tien jaar eerder, in I880. ${ }^{27}$ Onze conclusie spoort goed met inzichten die wij eerder heb-

27. Horlings en Smits, 'Private consumer expenditures', 2I-23. 


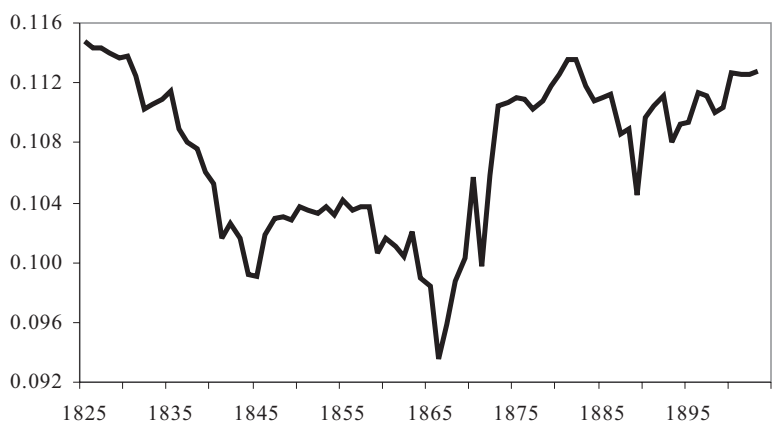

Figuur 2. Som van de gekwadrateerde residuen: consumptie met reeksbreuk

ben ontwikkeld en die hebben laten zien dat de Nederlandse economie in de tweede helft van de negentiende eeuw steeds meer de internationale conjunctuur gaat volgen. ${ }^{28}$ Ook in het geval van de ontwikkeling van de particuliere consumptie lijkt het steekjaar 1889 een breukvlak te zijn. Kennelijk is de ontwikkeling van de consumptieve bestedingen in sterke mate - en op positieve wijze - beïnvloed door de opgaande fase in de internationale conjunctuur vanaf de jaren negentig van de negentiende eeuw tot aan de Eerste Wereldoorlog.

Belangrijker dan de analyse van breukvlakken in consumptie is de speurtocht naar de determinanten van de ontwikkeling van de particuliere consumptie. In het werk van Horlings en Smits worden weliswaar een aantal van de in dit artikel genoemde verklarende variabelen bestudeerd, er wordt echter geen poging ondernomen om na te gaan welk belang de diverse variabelen hebben in de verklaring van het uiteindelijke groeipatroon van de consumptieve bestedingen. Daartoe gaan we nu over.

\section{Schattingsresultaten}

Het ECM model uit paragraaf 3, vergelijking (2), is zowel geschat voor de gehele negentiende eeuw als voor de boven gevonden deelperioden. De schattingsresultaten staan in Tabel I. De kolom met als label (I) laat de uitkomsten zien voor de gehele periode, de kolommen (2)-(5) die van de deelperioden.

Alvorens deze resultaten besproken worden is een aantal opmerkingen van belang. In de eerste plaats valt op dat niet alle determinanten van consumptie zijn opgenomen in de korte termijn. De interestvoet en de werkloosheid spelen wel een rol in de lange termijn, maar niet in de korte termijn. De reden hiervoor is dat het toevoegen van deze twee variabelen aan de korte termijn in geen enkele situatie significante coëfficiënten oplevert.

28. J.P.A.M. Jacobs en J.P. Smits, 'Conjunctuurbewegingen in Nederland gedurende de negentiende eeuw - met een internationale vergelijking', in: NEHA Jaarboek $6_{4}$ (200I) I78-I99. 
Ten tweede is in de langetermijn specificatie voor de gehele periode de coëfficiënt van het looninkomen, dat wil zeggen, de marginale consumptiequote, op één gezet. Vrije schatting levert een marginale consumptiequote groter dan één, maar niet significant afwijkend daarvan op. Een marginale consumptiequote die een hogere waarde heeft dan één is niet plausibel. Vandaar dat deze coëfficiënt is gefixeerd op één.

TABEL 1. ECM-schattingen (standaardfouten tussen haakjes)

\begin{tabular}{|c|c|c|c|c|c|}
\hline & $1815-1913$ & $1815-1844$ & $1845-1865$ & 1866-1888 & $1889-1913$ \\
\hline Variabelen & (I) & (2) & (3) & (4) & (5) \\
\hline \multicolumn{6}{|l|}{ Korte termijn } \\
\hline \multirow[t]{2}{*}{ Looninkomen } & $0.403^{*}$ & $0.247^{*}$ & 0.353 & $0.606 *$ & $0.648 *$ \\
\hline & $(0.069)$ & (O.III) & (0.2II) & (0.107) & (O.IIO) \\
\hline \multirow[t]{2}{*}{ Accijnzen } & $-0.079^{*}$ & $-0.049 *$ & $-0.09 \mathrm{I}^{*}$ & $-0.168 *$ & $-0.235^{*}$ \\
\hline & $(0.009)$ & (0.013) & (0.0I7) & $(0.022)$ & $(0.024)$ \\
\hline \multicolumn{6}{|l|}{ Lange termijn } \\
\hline \multirow[t]{2}{*}{ Aanpassingssnelheid } & $0.113^{*}$ & 0.083 & 0.456 & $0.8 \mathrm{I} 2 *$ & $0.585^{*}$ \\
\hline & $(0.049)$ & $(0.098)$ & $(0.269)$ & (0.I7I) & $(0.248)$ \\
\hline \multirow[t]{2}{*}{ Looninkomen } & I.००० & 0.523 & 0.645 & $0.816 *$ & $0.612 *$ \\
\hline & - & (I.047) & $(0.428)$ & (0.04I) & $(0.079)$ \\
\hline \multirow[t]{2}{*}{ Accijnzen } & $-0.146 *$ & -0.033 & $-0.144^{*}$ & $-0.194 *$ & $-0.264^{*}$ \\
\hline & (0.06I) & (0.150) & $(0.048)$ & $(0.023)$ & $(0.04 \mathrm{I})$ \\
\hline \multirow[t]{2}{*}{ Lange rente } & $0.115^{*}$ & $0.27 \mathrm{I}$ & 0.020 & $-0.049^{* * *}$ & 0.014 \\
\hline & (0.03I) & $(0.324)$ & $(0.045)$ & $(0.025)$ & $(0.042)$ \\
\hline \multirow[t]{2}{*}{ Werkloosheid } & 0.036 & 0.307 & 0.064 & $-0.033^{*}$ & -0.015 \\
\hline & (0.05I) & $(0.437)$ & $(0.050)$ & $(0.015)$ & (0.019) \\
\hline \multirow[t]{2}{*}{ Constante } & $0.683^{*}$ & 0.696 & 2.918 & $2.867^{*}$ & $4.185^{*}$ \\
\hline & (o.197) & $(3.772)$ & $(2.399)$ & $(0.304)$ & $(0.754)$ \\
\hline R-kwadraat (adj) & 0.479 & 0.308 & 0.588 & 0.783 & 0.865 \\
\hline Durbin-Watson & 2.395 & 2.482 & 2.139 & 2.363 & I. 852 \\
\hline
\end{tabular}

$*$ significant op 5 procent $* *$ significant op Io procent

Indien we de periode I8I5-I9I3 als één tijdvak beschouwen, valt op dat ofschoon er een significante invloed van accijnzen is, de groei van de particuliere consumptie vrijwel geheel door de ontwikkeling van het looninkomen 
wordt verklaard. ${ }^{29}$ Ofwel, vrijwel het gehele looninkomen werd in deze periode voor consumptieve doeleinden aangewend. Vanuit hedendaags perspectief mag een dergelijke conclusie wellicht ongeloofwaardig overkomen; de vraag doet zich immers voor of consumenten niet gespaard hebben. Echter, in het licht van de inkomenspositie van met name de arbeidersklasse in de periode voor I9I3 is deze conclusie zeer plausibel. Zeker tot halverwege de jaren zestig balanceerde het gros van de bevolking rondom het bestaansminimum. In de literatuur wordt zelfs vaak gesproken van een 'pre-industrieel levensritme' waarmee bedoeld wordt dat de consumptie van 'luxe producten' zoals vlees, kleding en schoeisel terugliep op momenten dat de prijzen van primaire voedingsmiddelen (met name brood) stegen..$^{30}$ Dit premoderne consumptiepatroon liet uiteraard weinig tot geen ruimte voor gezinshuishoudens om een substantieel deel van hun inkomen te sparen.

Hoewel voor de periode I8I5-I9I3 met name het looninkomen als determinant van consumptieontwikkeling naar voren komt, kunnen voor de diverse deelperioden interessante ontwikkelingen worden geconstateerd. Het blijkt dat in de verschillende subperioden uiteenlopende factoren de groei van de particuliere consumptie hebben aangestuurd. Allereerst heeft het looninkomen slechts in de periode $n a$ I 865 een significante langetermijn invloed op de consumptie. Hetzelfde geldt voor de accijnzen. Vooral in de laatste deelperiode (de jaren I889-I9I3) scoort deze variabele relatief sterk. Dit resultaat is zeer onverwacht aangezien de omvang van deze indirecte belasting in die periode bijzonder laag was en veel minder op het budget van arbeidersgezinnen drukte dan in de voorafgaande decennia het geval was. De sterkere score voor het looninkomen hangt uiteraard samen met het feit dat de periode van de 'loonstarheid' rond de jaren zestig doorbroken wordt op het moment dat de arbeidsmarkt niet langer door een structureel overschot van arbeid wordt gekarakteriseerd.

In het ECM-model zijn ook verklarende variabelen opgenomen die in eerder onderzoek onderbelicht zijn gebleven. ${ }^{3 \mathrm{I}}$ Allereerst kan gewezen worden op de werkloosheid, die in de periode I866-I888 sterk scoort. Deze timing is plausibel aangezien juist in deze periode de werkloosheid, onder invloed van het moderniseringsproces dat zich in deze jaren in de economie heeft voltrokken, sterk gedaald is. Dit heeft uiteraard tot een vergroting van de consumptie geleid. Ook de lange rente en de aanpassingssnelheid spelen in de periode I866-I888 een cruciale rol. Deze ECM-schattingen tonen dan ook aan dat de jaren zestig en zeventig van de negentiende eeuw inderdaad als een fase van

29. De coëfficiënt van de interestvoet is op de lange termijn ook significant, maar het positieve teken is niet plausibel.

30. Zie bijvoorbeeld Th. van Tijn, Twintigjaren Amsterdam. De maatschappelijke ontwikkeling van de hoofdstad van de jaren '50 der vorige eeuw tot 1876 (Amsterdam I965).

31. Horlings en Smits, 'Private consumer expenditure', 23-32. 
structurele transformatie in de richting van een 'moderne' economie kan worden gezien zoals in de literatuur vaak wordt gesteld. ${ }^{32}$

Met name de aanpassingssnelheid is in dit kader van belang. Deze parameter geeft aan hoe snel de consumptie in perioden van schommelingen weer naar zijn langetermijn evenwicht terugkeert. Tot halverwege de jaren zestig scoort deze parameter in het geheel niet. Daarna, en dan vooral in de periode I866-I888, blijkt dat de consumptie veel sneller dan voorheen in tijden van onevenwichtige ontwikkelingen weer naar het oorspronkelijke evenwichtsniveau terugkeert. Dit heeft alles te maken met de institutionele vernieuwingen die zich in de loop van de tweede helft van de negentiende eeuw hebben voltrokken en waardoor het economisch verkeer steeds meer door marktkrachten werd bepaald en minder werd afgeremd door klemmende overheidsmaatregelen. Hierdoor konden economische actoren steeds sneller en adequater op eventuele economische schokken reageren.

De schattingsresultaten van de eerste en de tweede deelperiode zijn statistisch gezien beduidend minder bevredigend dan de resultaten voor de tweede helft van de eeuw. Het belangrijkste probleem spitst zich toe op de significantie van de aanpassingssnelheid. In beide perioden namelijk is deze coëfficiënt niet significant waardoor de rechtvaardiging voor een Есм wegvalt. Deze conclusie is niet opzienbarend als wordt gekeken naar de tijdreekseigenschappen van de reeksen in die perioden. Toetsen op tijdreekseigenschappen zoals beschreven in paragraaf 3 wijzen uit dat zowel de consumptie, de reële lonen als de accijnzen in de eerste helft van de eeuw stationair zijn, waardoor niet voldaan is aan de belangrijkste voorwaarde voor een Есм. In de tweede helft van de negentiende doet dit probleem zich niet voor. In de periode I866-I888 en I889-I9I3 kan de nulhypothese dat consumptie, reële lonen en accijnzen I(I) zijn niet worden verworpen. ${ }^{33}$

Voor de periode I8I5-I844 en I845-I865 zijn derhalve aanvullende schattingen uitgevoerd. De resultaten staan in Tabel 2. De modelspecificaties zijn zowel in niveaus geschat als in eerste verschillen. In het eerste geval heeft het niveau van een determinant invloed op het niveau van de consumptie, in het tweede geval beïnvloedt de groei van een determinant de groei van de consumptie. Behalve in specificatie (6i), is in alle specificaties een zogenoemde autoregressieve (AR) component van de eerste orde toegevoegd. In specificatie (6i) heeft de toevoeging van een AR-term grote invloed op de hoogte van de marginale consumptiequote, in de andere specificaties is dat

32. J.P. Smits, Economische groei en structuurveranderingen in de Nederlandse dienstensector, 1850-1913. De bijdrage van handel en transport aan het proces van 'moderne economische groei' (Amsterdam i995) hoofdstuk 9.

33. Hierbij zij vermeld dat het onderscheidend vermogen van ADF toetsen klein is bij reeksen met grote breuken, met andere woorden, het is niet goed mogelijk te discrimineren tussen een I(I) reeks en een stationaire reeks met een breuk. 
niet het geval. Om die reden is deze component in specificatie (6i) achterwege gelaten.

TABEL 2. Aanvullende schattingen: 1815-1844 en 1845-1865 (standaardfouten tussen haakjes)

\begin{tabular}{|c|c|c|c|c|c|c|c|c|}
\hline \multirow[b]{2}{*}{ Variabelen } & \multicolumn{4}{|c|}{ Niveau } & \multicolumn{4}{|c|}{ Eerste verschillen } \\
\hline & $\begin{array}{c}1815-1844 \\
(6 i)\end{array}$ & $\begin{array}{c}1815-1844 \\
\text { (6ii) }\end{array}$ & $\begin{array}{c}1845^{-1865} \\
\text { (7i) }\end{array}$ & $\begin{array}{c}1845^{-1865} \\
\text { (7ii) }\end{array}$ & $\begin{array}{c}1815-1844 \\
(8 \mathrm{i})\end{array}$ & $\begin{array}{c}1815-1844 \\
(8 \mathrm{ii})\end{array}$ & $\begin{array}{c}1845^{-1865} \\
\text { (9i) }\end{array}$ & $\begin{array}{c}1845^{-1865} \\
\text { (9ii) }\end{array}$ \\
\hline \multirow[t]{2}{*}{ Looninkomen } & $0.877^{*}$ & - & $0.385 *$ & - & 0.160 & - & 0.243 & - \\
\hline & $(0.092)$ & - & (0.I75) & - & $(0.096)$ & - & $(0.164)$ & - \\
\hline \multirow[t]{2}{*}{ Accijnzen } & $-0.044^{*}$ & $-0.028 *$ & $-0.076 *$ & $-0.065^{*}$ & $-0.037^{*}$ & $-0.030 *$ & $-0.057^{*}$ & $-0.046 *$ \\
\hline & $(0.02 \mathrm{I})$ & $(0.012)$ & (0.013) & (O.OII) & (0.010) & (0.0I0) & (0.0I8) & (0.0I4) \\
\hline \multirow[t]{2}{*}{ Voedselprijzen } & - & -0.017 & - & $-0.143^{*}$ & - & $-0.04 \mathrm{I}$ & - & -0.086 \\
\hline & - & $(0.060)$ & - & $(0.055)$ & - & $(0.044)$ & - & $(0.050)$ \\
\hline \multirow[t]{2}{*}{$\mathrm{AR}(\mathrm{I})$-term } & - & $0.973^{*}$ & $0.640 *$ & $0.53 \mathrm{I}^{*}$ & $-0.347^{* * *}$ & $-0.35^{1 * * *}$ & -0.366 & $-0.467 * *$ \\
\hline & - & $(0.035)$ & $(0.242)$ & $(0.234)$ & (0.I79) & (0.I8I) & $(0.280)$ & $(0.248)$ \\
\hline \multirow[t]{2}{*}{ Constante } & I. $476 *$ & $6.868 *$ & $4.452^{*}$ & $7.258 *$ & $0.015^{*}$ & $0.018 *$ & 0.005 & 0.004 \\
\hline & $(0.4 \mathrm{I} 2)$ & (I.II4) & $(0.965)$ & $(0.266)$ & $(0.004)$ & $(0.003)$ & $(0.005)$ & $(0.005)$ \\
\hline Durbin-Watson & 0.765 & 2.589 & I. 850 & I.957 & 2.223 & 2.189 & $2 . \mathrm{II} 5$ & 2.150 \\
\hline
\end{tabular}

* significant op 5 procent $* *$ significant op ro procent

Wat betreft de significantie van de coëfficiënten lopen de schattingsresultaten in niveaus en eerste verschillen niet veel uiteen. Het enige opzienbarende verschil zit in de geschatte coëfficiënt van het looninkomen. Voor de niveauschattingen is deze coëfficiënt in beide deelperioden significant, voor de schattingen in eerste verschillen is dat niet het geval. Opvallend is dat de marginale consumptiequote in de periode I845-I865 veel lager ligt dan in de voorgaande periode. De accijnsdruk wordt echter beduidend hoger, zoals we eerder al aangegeven hebben.

Het opnemen van voedselprijzen in sommige specificaties in Tabel 2 verdient aparte vermelding. In de literatuur wordt de koopkrachtontwikkeling in de eerste helft van de negentiende eeuw nauw in verband gebracht met de ontwikkelingen in de voedselprijzen. Om dit effect na te gaan, is in specificatie (6ii), (7ii), (8ii) en (9ii) het reële loon vervangen door de prijsindex van de primaire voedingsmiddelen. Zoals verwacht is de coëfficiënt van de primaire voedselprijzen in alle gevallen negatief, maar alleen voor de niveauschattingen in de periode I845-I865 worden significant van nul afwijkende parameters gevonden. 


\section{Conclusie}

Dit artikel kijkt met een moderne bril naar de determinanten van Nederlandse consumptie in de negentiende eeuw. Is de relatie tussen consumptieve vraag en haar determinanten stabiel geweest of treden er verschuivingen op over deelperioden?

Onze analyse bestond uit twee delen. Allereerst is onderzocht of er deelperioden te onderscheiden zijn in de tijdreeks van consumptie in de lange negentiende eeuw. Hiermee is een statistisch fundament gelegd onder eerder empirisch onderzoek van Horlings en Smits. In grote lijnen sluit de door ons gevonden periode-indeling aan bij die van hen. Echter daar waar zij een breuk legden in I880, kwam uit onze analyse duidelijk I889 als breukjaar naar voren, een uitkomst die beter aansluit bij internationale conjuncturele ontwikkelingen aan het einde van de negentiende eeuw. Een belangrijke uitkomst in dit verband is het verschil in tijdreekseigenschappen in de eerste en tweede helft van de negentiende eeuw. In de eerste helft blijkt de consumptie reeks (trend-)stationair te zijn, terwijl voor de tweede helft consumptie nietstationair of I(I) is en wordt gedreven door zijn eigen verleden. Deze observatie geldt overigens ook voor het reële loon. De implicaties van deze transformatie zullen in een vervolgstudie worden onderzocht.

Vervolgens is de relatie tussen consumptieve vraag en haar determinanten formeel onderzocht, daarmee de ad-hoc benadering van Horlings en Smits ver achter ons latend. Wij hanteren als kader het standaard dynamische model voor consumptie, een zogenoemd error correction model waarin afwijkingen van het langetermijn evenwicht de verandering in consumptie kunnen beïnvloeden naast veranderingen in de determinanten. Schattingen over de gehele periode en deelperioden brengen verschillen in de aanpassingssnelheid in de richting van het langetermijn evenwicht aan het licht. In de eerste helft van de negentiende eeuw blijkt er geen sprake te zijn geweest van een langetermijn evenwichtsrelatie voor consumptie. De twee deelperioden in de tweede helft van de lange negentiende eeuw laten een duidelijk verschil in de aanpassingssnelheid zien. In de loop van de tijd werden steeds meer institutionele belemmeringen die het goed functioneren van markten in de weg stonden, weggenomen.

Daarnaast geven de schattingen inzicht in het belang van de determinanten van consumptie over de tijd. Schattingsuitkomsten over de gehele periode suggereren dat er alleen een rol is weggelegd voor reële lonen (met een langetermijn parameter van één) en accijnzen op de korte en de lange termijn en de interestvoet op de lange termijn. Gebruikmakend van de gevonden periodisering kunnen we concluderen dat werkloosheid en de interestvoet ook van invloed zijn geweest op de consumptieve vraag in de periode I866-I888. Daarmee heeft dit onderzoek naar de determinanten van veranderingen in de consumptie ons een dieper inzicht gegeven in het hoe en waarom van de opkomst 
van het proces van moderne economische groei in Nederland vanaf de jaren zestig van de negentiende eeuw.

\section{Over de auteurs}

Jan Bonenkamp studeert algemene economie aan de Faculteit der Economische Wetenschappen van de Rijksuniversiteit Groningen. Hij participeert in het honours-traject van de faculteit. In het kader daarvan houdt hij zich voornamelijk bezig met conjunctuuronderzoek maar ook met economisch-historische vraagstukken.

Adres: Fivelstraat 6A, 97I5 BG Groningen, e-mail: janbonenkamp@hotmail.com

Jan P.A.M. Jacobs studeerde econometrie en promoveerde aan de Rijksuniversiteit Groningen. Hij is als onderzoeker verbonden aan het ccso en de Vakgroep Algemene Economie van de FEw van de Rijksuniversiteit Groningen. Hij houdt zich bezig met macro-economisch modelleren en conjunctuuronderzoek met als belangrijkste publicatie: Econometric Business Cycle Research (Kluwer Academic Press).

Adres: RUG, Postbus 800, 9700 Av Groningen, e-mail: j.p.a.m.Jacobs@ eco.rug.nl

Jan-Pieter Smits studeerde geschiedenis en promoveerde aan de Vrije Universiteit. Hij was coördinator van het project 'Nationale Rekeningen' en is momenteel vice-president van het Groningen Growth and Development Centre. Tevens leidt hij met Johan Schot de onderzoeksgroep 'Globalisation, technological change and economic development' in het N.W. Posthumus Instituut. Momenteel is hij U D aan de Rijksuniversiteit Groningen waar hij zich bezighoudt met onderzoek naar de relatie tussen lange termijn economische groei, technologische vernieuwing en institutionele ontwikkeling.

Adres: RuG, Postbus 800, 9700 Av Groningen, e-mail: j.p.smits@eco.rug.nl 